\title{
Strong Credit Demands, But No "Crunch" in Early 1973
}

\author{
by ROGER W. SPENCER
}

\begin{abstract}
N RECENT months many observers in the financial community have been concerned about the potential emergence of a credit crunch. Last fall, economic forecasters indicated that the occurrence of such a crunch was a major potential blight on an otherwise optimistic outlook for 1973. In many respects the economic conditions anticipated in 1973 were viewed as being similar to those which prevailed in 1966 and 1969, two recent years of widespread financial stress. Strong real output growth, high levels of capacity utilization, and advancing price pressures were experienced in those years and were projected to reemerge in 1973.
\end{abstract}

In 1966 and 1969 , the accelerating inflationary pressures led stabilization authorities to take restrictive measures in order to restrain the upward spiral of prices. A side effect of those efforts was the creation in 1966 and 1969 of conditions in the financial markets which became popularly characterized as a "credit crunch."

This article reviews characteristics common to the two credit crunch periods, and then examines financial and business conditions in early 1973. The differences and similarities between the earlier periods and developments so far in 1973 are emphasized. Currently, there are strong credit demands in the economy, as there were in the 1966 and 1969 credit crunch periods. However, substantial differences between the present and earlier periods remain.

\section{D

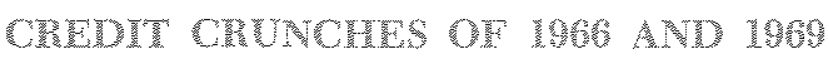

The term "crunch" is indicative of developments wherein rapidly changing supply and demand forces, in combination with non-market interest regulations, sharply alter the flow of credit away from normal channels. This distortion of normal credit flows was the clearest single element common to both the 1966 and 1969 credit crunches. ${ }^{1}$ Credit seekers who were affected by the change in flows included business firms, govermments, individuals, and financial institutions.

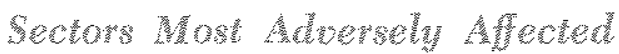

In the past two crunch periods, certain financial institutions were among the most publicized victims of the financial wrenching. Since financial intermediaries obtain funds from savers and extend loans to borrowers, they are particularly vulnerable to pronounced changes in credit flows. In both crunch situations, these institutions were "disintermediated" when the rates they were permitted to pay savers did not rise as rapidly as interest rates in the open market. For a while the intermediaries were able to meet a continued high demand for funds by liquidating shortterm securities or by borrowing. Eventually, however,

'Some of these distortions continued into the immediately succeeding years. 
they were forced to curb loan extensions because of the inability to attract new funds.

Individuals and firms seeking to obtain funds from institutions whose borrowing rates were subject to legal ceilings probably found the available supply of credit allocated on a non-price basis - first come, first served, for example. In cases in which ceilings on interest rates did not exist or were ineffective, the price mechanism functioned to allocate the credit supply. Some borrowers likely found the prices they had to pay for credit were sufficiently high as to discourage them from borrowing at that time. If they anticipated the cost of credit would fall sometime later relative to their expected return (however measured), they simply postponed attempts to obtain funds. Such actions would tend to lower the immediate demand pressure on financial intermediaries.

Sources of funds to financial intermediaries at any time are strongly influenced by changes in the interest rates that the intermediaries are permitted to pay to attract deposits. The ability of one intermediary to attract deposits from another by an incremental increase in offering rates has probably been enhanced during periods of financial stress. High open market rates likely caused some disintermediation among all the thrift institutions. One result was increased borrowing on the part of the intermediaries.

Member banks increased borrowing from the Federal Reserve Banks, and savings and loan associations tumed to the Federal Home Loan Bank Board. In some cases the Federal Reserve chose to restrict bank borrowing at the given discount rate, and the Federal Home Loan Bank Board encountered exceptionally high costs in marketing its own securities on the open market. These actions contributed to the crunch situation for those banks and savings and loans deprived of a large part of both their primary and secondary sources of funds.

The housing sector was also greatly influenced by these financial developments. With savings and loan associations, mutual savings banks, and commercial banks forced to curb the advance of housing loans, Federal or semi-Federal agencies such as the Federal National Mortgage Association (FNMA) and the Government National Mortgage Association (GNMA) attempted to make available to the housing seotor funds that they had been able to attract on the open market. The agency support was particularly significant to the housing sector at times when the mortgage activity of life insurance companies had been curbed because of the large volume of policy loans granted to policyholders. The relatively low interest charge set in the insurance contracts made this source of funds quite attractive to individuals and firms.

Most state and local governments are subject to substantial constraints on their capacity to obtain funds through bond issuance or tax increases. Like some financial intermediaries and high risk borrowers, many of these governments have curbed their operations during periods of financial stress. The Federal Govemment, on the other hand, is less limited in its ability to tax and/or issue bonds when it desires to obtain additional funds. In fact, this ability to borrow from the public at high interest rates (at least in the short-term market) at times has likely resulted in a shift of funds from financial intermediaries and state and local governments to the Federal Government.

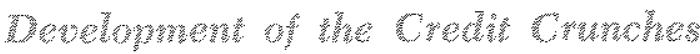

Ironically, the origins of past credit crunch periods may be traced to stimulative monetary policy actions. Expansionary policies have been appropriately taken during recessionary periods to stimulate real economic activity. However, in periods when economic activity is already moving at a brisk pace, and resource utilization is very high, monetary stimulus may eventually precipitate a credit crunch.

The demand for funds in such periods has been sufficient to induce a rise in interest rates. Frequently, monetary authorities have resisted the rise in market interest rates by stepping up the pace at which they supplied reserves to the banking system. The increases in reserves have led to expanded flows of credit, increased growth in the money stock, and temporary reductions in or a leveling off of interest rates.

Increased growth in money, relative to the prevailing trend, has led to increases in the growth of total spending. The rise in the pace of spending has been accompanied by increases in the demand for credit, and, simultaneously, upward interest rate pressures. Advances in the growth of total spending that have occurred at relatively high levels of employment have been accompanied by greater inflationary pressures. To the extent that price increases come to be anticipated, lenders demand and borrowers are willing to pay still higher interest rates. Only when some outside source of funds, such as the Federal Reserve Banks, has continued to supply credit at an accelerating rate has financial stress been postponed. The cost of such postponement has been escalating inflation. 
However, at some point in the inflation cycle, the monetary authorities have undertaken restrictive actions. These actions have been reflected in a slowing in the rate of growth of monetary aggregates and a temporary further rise in interest rates, both of which occurred in 1966 and 1969. Subsequently, as a result of the restrictive policy actions, credit extensions have fallen and interest rate declines have accompanied a slowing in the pace of total spending.

The credit erunch periods were significant not only because of the financial wrenchings which occurred at that time, but also because such periods were followed by a slowing in real economic activity. The credit crunch of 1966 was followed by the mini-recession of 1967, and the crunch of 1969 preceded the recession of 1970. Current business conditions and financial developments suggest some similarities with these earlier periods, but the differences are significant and notable.

\section{COMPARISON OF DUSWNESS AND PNANCWA CONDITONS}

As in 1966 and 1969, total spending, output, and employment indicators currently reflect a rapid growth in economic activity. A brief slowing in certain monetary aggregates, and a rise in some interest rates resemble patterns observed in 1966 and 1969. However, important differences remain.

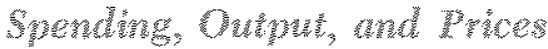

Rising prices and increased growth of real output are associated with growing credit demands. In the early recovery stage of the business cycle, output tends to rise rapidly while the inflation rate changes slowly. Thus, credit demands at this stage are associated primarily with output gains as businesses borrow to finance plant and equipment expansion and inventory building, and consumers borrow to finance increased purchases. In the latter stage of a recovery, further increases in output are more difficult to achieve because resources are more highly utilized. However, credit demands continue to rise as price advances tend to accelerate and anticipations of further inflation contimue to build.

In early 1973, both real output and prices have risen rapidly. A deceleration in the rate of increase of many prices, which began in late 1970 , was reversed late last year. At the same time, the sharp pickup in real output, which began at the end of 1971 , has continued into early 1973. The associated gains in total spending have been at rates above those which prevailed in the 1966 and 1969 credit crunch years.

A 13.1 percent annual rate of advance of total spending in the two-quarter period ending in March this year surpassed all other two-quarter gains since 1951. It is not clear, however, that the credit demand pressures created by such rapid price and output advances are any greater than those which prevailed in 1966 and 1969. Some observers argue that growth in credit demands is not based solely on the price and output movements in the present and immediate past, but also on those which have occurred over time. ${ }^{2}$ The 1966 and 1969 credit experiences were preceded by longer periods of output and price build-ups than have developed since the rather sluggish recovery year of 1971 .

\section{Wonetwi Agregates}

The fact that some interest rates recently have been rising while a slowing in the rate of growth of the money stock has also occurred has led some observers to conclude that the monetary authorities have adopted a highly restrictive policy stance. Other evidence indicates that such a conclusion might be premature.

The accompanying chart of the narrowly defined money stock $\left(\mathrm{M}_{1}\right)$ indicates that money stock growth slowed sharply from its earlier trend for extended periods of time in 1966 and 1969 . In fact, the money supply did not increase at all from April 1966 to January 1967. In both cases the slowing lasted for at least nine months.

Money stock growth in early 1973 has decelerated from the 7.2 percent annual rate of increase from fourth quarter 1970 to fourth quarter 1972. During the six-month period from November last year to May 1973 , the money stock rose at a 6.4 percent annual rate, only slightly less than the $1970-72$ rate. ${ }^{3}$ The slowing which occurred in 1966 and 1969 , by way of contrast with the recent period of deceleration, repre-

\footnotetext{
"The St. Louis Model, for example, features a short-term interest rate equation in which price and output changes are lagged over a ten-quarter period and a long-term interest rate equation in which price and output changes are lagged over a sixteen-quarter period. See Leonall C. Andersen and Keith M. Carlson, "A Monetarist Model for Economic Stabilization," this Review (April 1970), pp. 14-15.

"The money stock rose at an abnormally high 14.1 percent rate from November 1972 to December and declined at 0.5 pereent rate from Decenber 1972 to January. The choice of November avoids the distortion introduced into rates of change calculations from abnomal base periods such as December or January.
} 


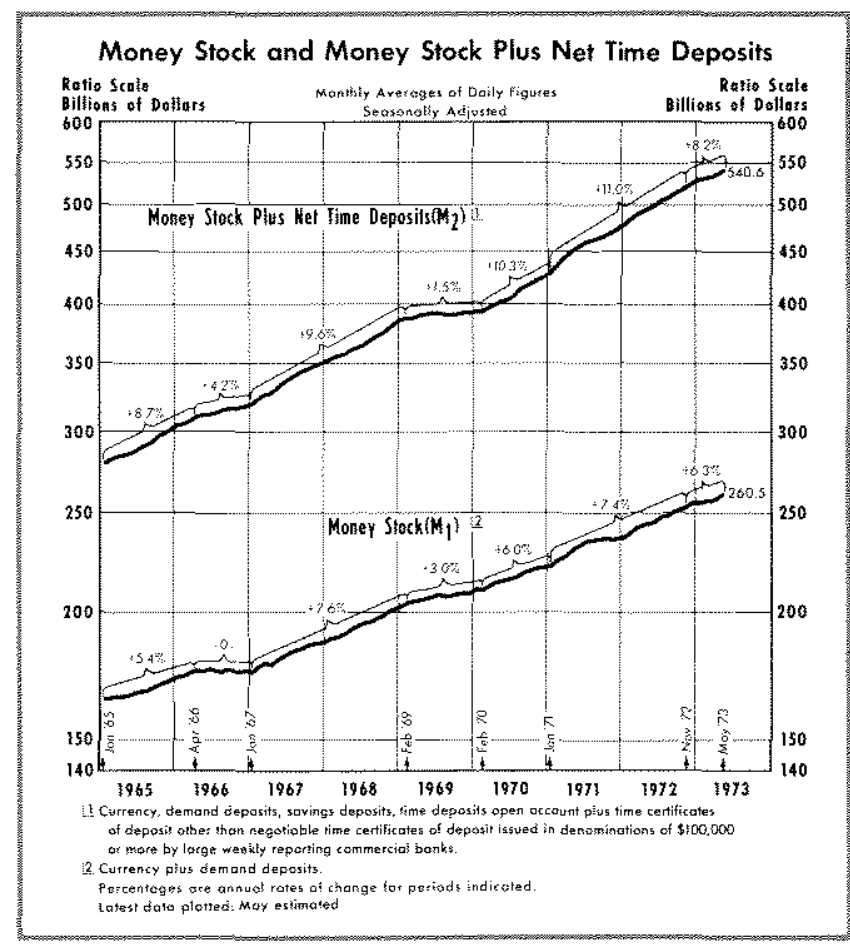

sented a sharp decline from the prevaling trend rates. Moreover, the slowing in the growth of money in 1973 has occurred over fewer months than in 1966 and 1969.

The accompanying chart also indicates that the movements of money stock plus net time deposits $\left(\mathrm{M}_{2}\right)$ have been similar to those of $\mathrm{M}_{1}$ over approximately the same periods. A marked and sustained slowing in $\mathrm{M}_{2}$ growth occurred in 1966 and 1969 , but the slowing thus far in 1973 is neither so pronounced nor so prolonged. From an annual rate of increase of 11 percent in the 1970-72 period, $\mathrm{M}_{2}$ growth slowed to an 8.6 percent rate of increase in the six months ending in May 1973.

The Federal Reserve does not exercise absolute control over either $M_{1}$ or $M_{2}$ in the short run. The behavior of the public, commercial banks, and the Treasury also affect monetary growth. Over a longer period, the growth of money is dominated by changes in the monetary base, the uses of which are bank reserves and currency in the hands of the public.4

The monetary base slowed markedly in 1966 and 1969 in a pattern roughly comparable with that of both $\mathrm{M}_{1}$ and $\mathrm{M}_{2}$. From November 1972 to May 1973, however, growth of the monetary base did not slow.

"See Leonall C. Andersen and Jerry L. Jordan, "The Monetary Base - Explanation and Analytical Use," this Review (August 1968), pp. 7-11.

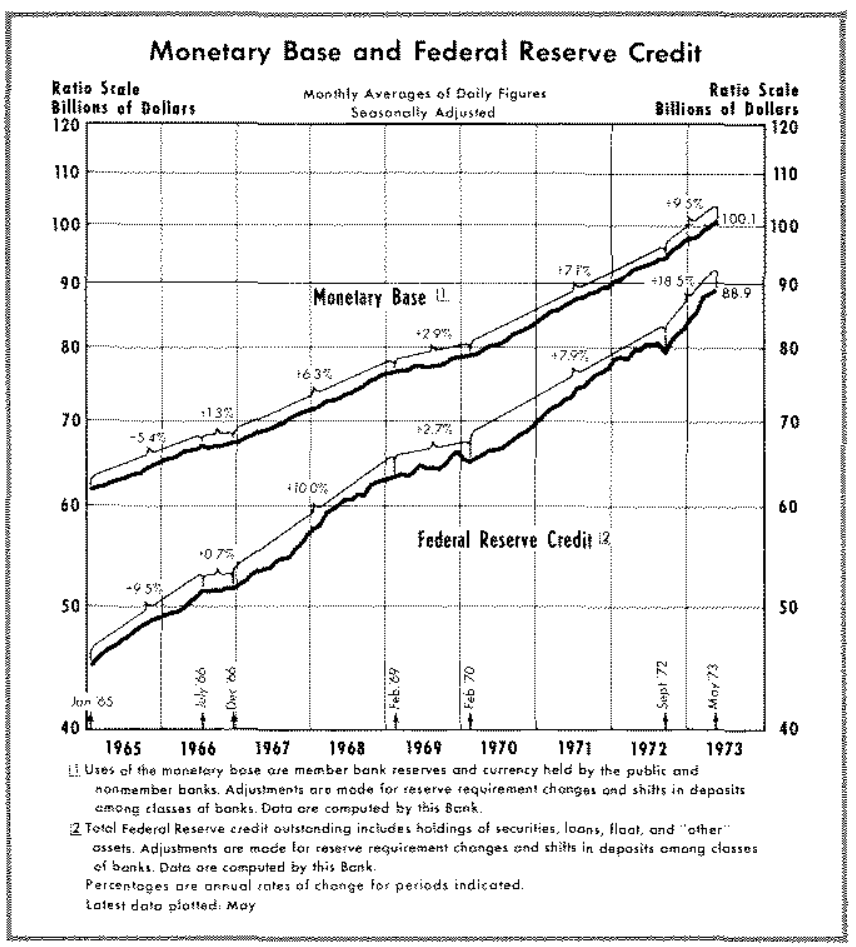

The base increased at an 8 percent annual rate in the six-month period ending in May, compared with a 7.8 percent rate of increase in the preceding two years. Largely because of the continued increase in the monetary base in recent months, there is a strong possibility that the recent slowing in money growth was a temporary result of the irregular and unusual pattern of Treasury deposits, and the recent sharp rise in large negotiable certificates of deposit (CDs)." Thus, changes in the rate of growth of the monetary base do not support the view that the monetary authorities have recently adopted a strongly restrictive stance.

EUnusual Treasury deposit flows accounted for much of the abnormal rise in the money stock in December 1972 and the subsequent slowing in the early months of this year. In December, the Treasury ran dowi its balances at commercial banks while making the initial revenue sharing payments to state and local govermments. Demand deposit balances of the Federal Govemment, tnlike the balanees of state and local goverments, are not counted as part of the money stock.

Ir early 1973, Treasury deposit balances at commercial banks rose more rapidly than usual because of continued overwithholding on the part of the public and the 'Treasury's relatively slow pace in meeting the large volume of tax refunds. Two other factors which contributed to a slowing in the rate of growth of the money stock, but which had no effect on the monetary base, were a rapid rise in the growth of commercial bank certificates of deposit and an increase in the demand for currency relative to demand deposits The growth in CDs, which absorbs reserves otherwise available for private demand deposits, is attributable in part to the relatively low commercial bank prime loan rates compared to rates available to corporate borrowers in the commercial paper market. To neet the increased loan demand, banks bid aggressively for CD funds. 
Federal Reserve credit and reserves available to support private nonbank deposits, two additional measures of monetary actions, also have grown more rapidly this year than in the two preceding years. In 1966 and 1969 both measures slowed substantially from their prevailing trends.

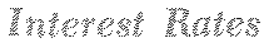

One significant characteristic of a credit crunch situation is the upward movement of various interest rates. The rise in open market interest rates above legal rate ceilings was one of the clearest common elements in the disintermediation of financial intermediaries in 1966 and 1969.

Market interest rates, which reflect demands for and supplies of credit, have risen sharply in recent months. Increases in interest rates since December 1972 have been particularly marked for short-term funds. In the first five months of this year, three-month Treasury bill rates have increased 129 basis points, four- to six-month commercial paper rates 182 basis points, and corporate Aaa bond rates 21 basis points.

The levels of the short-term rates are currently near the level of the long-term Aaa corporate bond rate. At 7.36 percent in the first week of June, the bond rate was 29 basis points above the Treasury bill rate and 47 basis points below the commercial paper rate.

In only two instances in the $1960-72$ period did the commercial paper rate rise above the long-term bond rate. The two periods spanned January 1966 through March 1967 and April 1969 through May 1970. The commercial paper rate rose well above the long-term rate on each of those occasions, reaching a peak of 65 basis points above the corporate bond rate in the first instance (November 1966) and 157 basis points in the second (July 1969). Thus, although the commercial paper rate in early June was high relative to the Aaa corporate bond rate, the differential was not as great as in the past credit crunch periods.

\section{S}

The sharp rise in open market short-term rates has begun to affect financial intermediaries whose administered rates have risen more slowly. Governmental and foreign influences on U.S. interest rates will be of particular significance over the next several months.

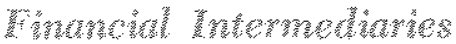

Commercial banks and other savings institutions are among the first to be affected by financial stress.

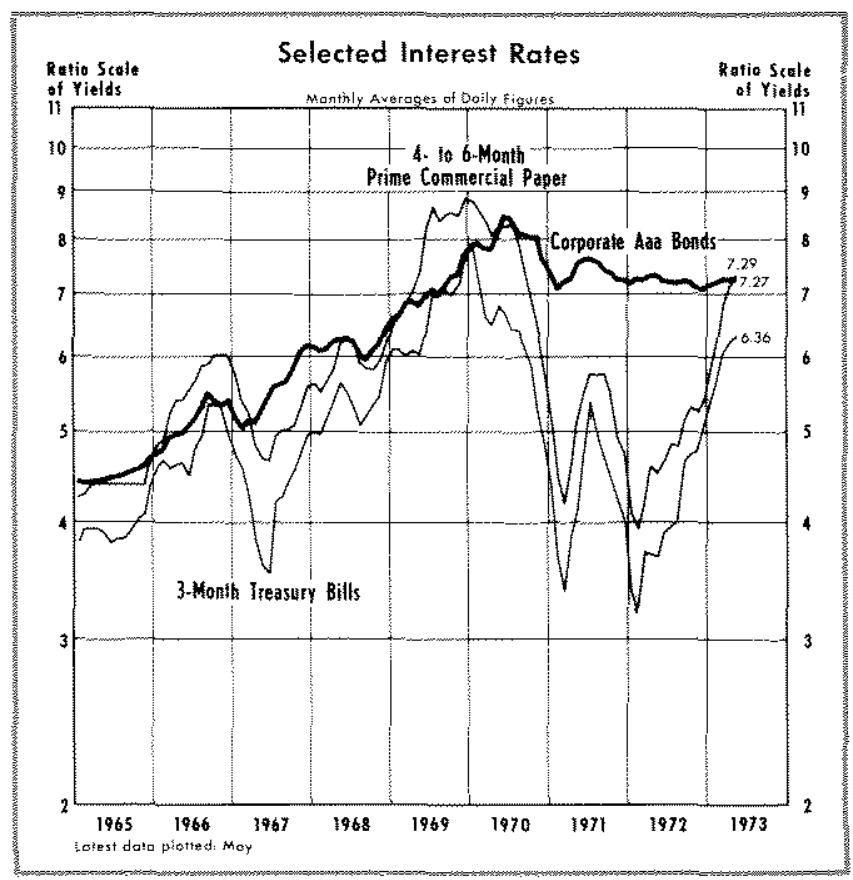

Changes in their asset-liability positions are transmitted rapidly to other areas, such as the housing market.

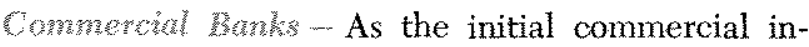
stitution through which monetary actions are reflected, commercial banks played an important role in the credit crunch periods. For the most part, recent commercial bank data suggest only minor similarities with developments in earlier periods of credit stress. For example, instead of slowing as in 1966 and 1969, large commercial bank certificates of deposit accelerated from a 32.3 percent increase in the 1970-72 period to a rate in excess of 100 percent in the first five months of 1973. The rapid rise in CDs in recent years was facilitated by the removal of interest ceilings on 30-89 day CDs in June 1970. Ceilings were removed from all CDs of $\$ 100,000$ or more in May 1973.

Bank credit, which consists of loans and investments, slowed markedly in 1966 and 1969. In the first five months of 1973 , bank credit increased at a 16.9 percent rate, compared to a 14.7 percent rise in $1972 .{ }^{\circ}$

\footnotetext{
"Over time, bark credit and the money stock tend to move in a similar pattern. In some short periods, as in early 1973 , this tendency has not been observed. When there is a rise in the interest rate that banks are permitted to pay on certificates of deposit, banks are able to extend additional credit even if bank teserves are held constant. A given amount of bank reserves supports far more certificates of deposit (CDs) than demand deposits because of the much lower reserve requirements for CDs. (A maryinal reserve requirement of 8 percent on increased holdings of large CDs was recently inposed.) Large CDs, however, are rarely considered money. The rise in one component of bank liabilities (CDs) is ac-
} 


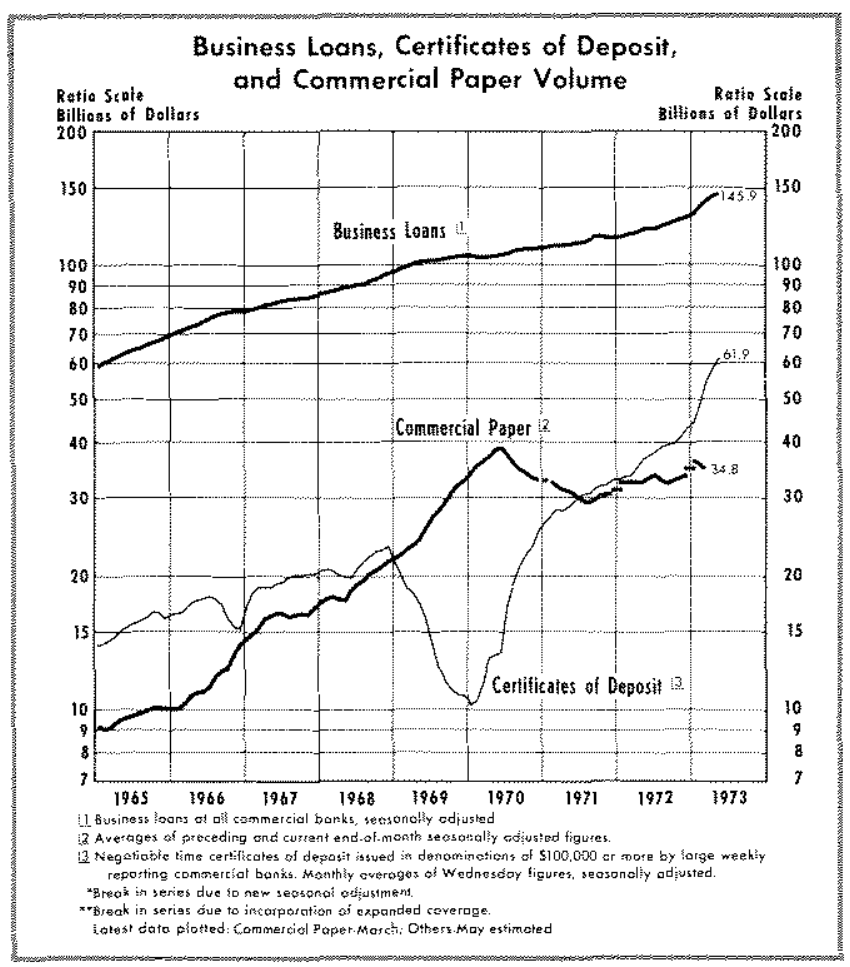

Most of the recent gains in bank credit have been in the form of loans, particularly business loans. Because prime business loan rates have been restrained somewhat by the Committee on Interest and Dividends, bank loans have been a relatively attractive source of funds to large business firms. In fact, in view of the difference in interest rates on bank loans to businesses and the yields available on large CDs, it is likely that large business firms increased both their outstanding loans from banks and their holdings of CDs.

The fact that most of the recent advances in bank credit have been accounted for by increases in loans, rather than securities, is in accord with 1966, 1969 developments. ${ }^{7}$ In 1966 and 1969 security holdings of banks declined for several months as banks sought to accommodate loan demand. In the five month period ending in May 1973, bank security holdings remained unchanged, compared with a 9 percent rise in the preceding year.

companied by a fall in another (demand deposits or time deposits other than CDs). Thus, a short-term change in the mix of bank liabilities may result in a rise in bank credit and a decline in the money supply,

"Since the eurrent pertod is not one of financial stress of the nature observed in 1966 and 1969 , the rapid expansion of loans relative to securities reflects, in part, the relatively low prime bank loan rate of recent months. In early Jme 1973 , a prime bank loan rate of 7.5 percent was about 33 basis points below the commercial paper rate, compared with an average of almost 50 basis points above in 1972 .

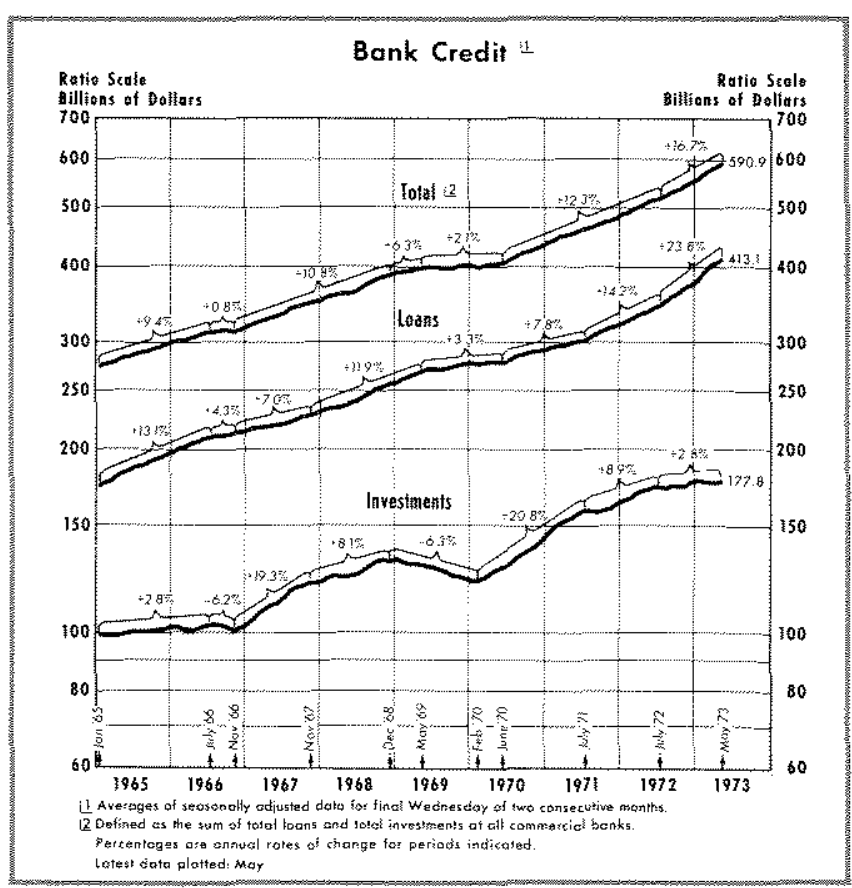

Banks probably find it profitable in the long run to continue making loans to their better customers in times of financial stress rather than extending credit to other sectors such as the Government security market. In other words, rates of return on loans (measured to include long-run considerations) in high interest rate periods surpass the yields on securities. State and local government securities are at a particular disadvantage in such times because of the statutory ceilings on yields of their bond issues.

Business loans have accounted for much of the increase in bank loans in early 1973. These loans increased at a 34.4 percent annual rate in the first five months of this year, compared with about an 11 percent rise in the preceding twelve months. Real estate loans have slowed in early 1973 from their rapid rate of increase in 1972, while, consumer loan growth has picked up somewhat. Consumer debt of all sorts is currently quite high, perhaps reflecting an optimistic income and employment outlook and/or a desire to "beat" future inflation.

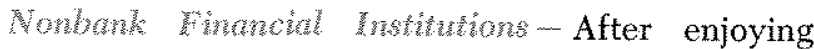
two excellent years in terms cf deposit gains in 1971 and 1972, savings and loan associations and mutual savings banks appear to have experienced somewhat less success in early 1973. The recent rise in open market interest rates has probably contributed to the slowing in deposits at both institutions from a 17 percent increase in the year ending in December 1972 to a 12 percent annual rate of increase in the first five months of 1973 . 


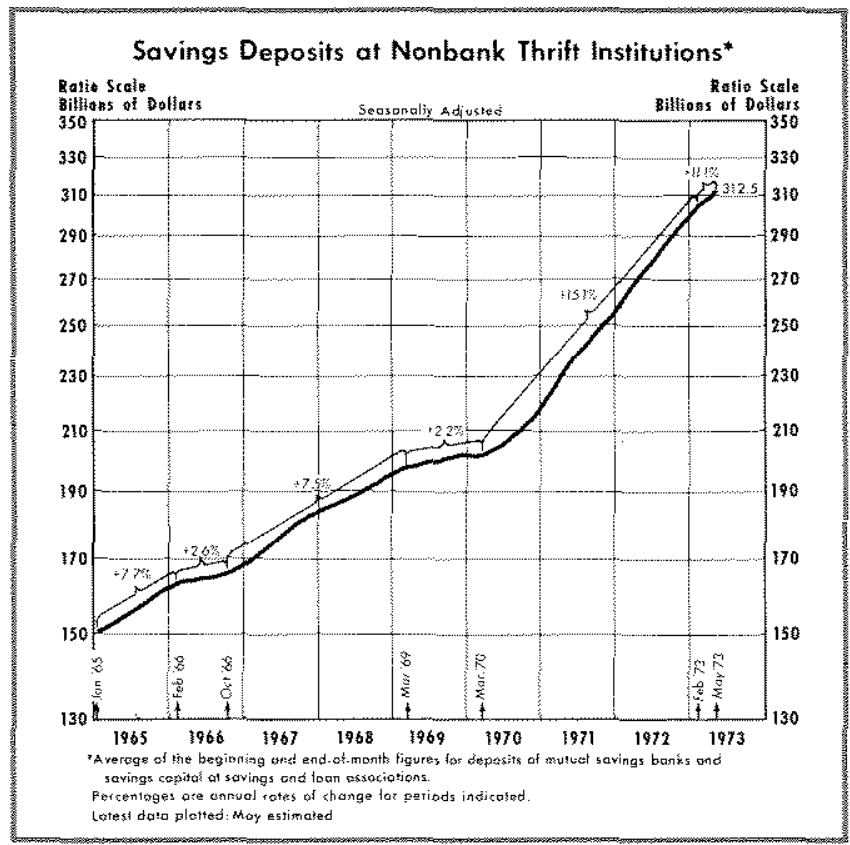

In 1966 and 1969 , the ability of the small saver to purchase a high-yielding Treasury bill by withdrawing as little as $\$ 1,000$ from a savings and loan or mutual savings bank account likely was associated with the marked slowing in deposits at nonbank thrift institutions in those two years (see chart). In March 1970 , original Treasury security issues in less than $\$ 10,000$ denominations were discontinued. As a result, the small saver is now less likely to withdraw his institutional savings during high interest rate periods. More wealthy individuals and firms can still easily switch assets in accord with changing open market interest rates. The ability of the savings inter mediaries to retain these accounts was enhanced in 1970 by the relaxation of interest rate ceilings on certain large deposits. In May 1973 interest restriotions on savings certificates of $\$ 100,000$ or more were removed for most savings and loan associations.

As an indication that the savings institutions are experiencing some changes in their savings flow positions, the withdrawal ratio (withdrawals relative to new savings) at savings and loan associations rose to an average of 74 percent in the first four months of 1973, compared with 64 percent over the same period in 1972. This ratio averaged 92 percent in both 1966 and 1969.

Savings and loan borrowings, primarily from the Federal Home Loan Bank Board (FHLBB), have also begun to increase, although not nearly as much as in 1966 or 1969. The FHLBB, in turn, may issue more of its own securities on the open market, as it did in the two earlier crunch years, in order to meet

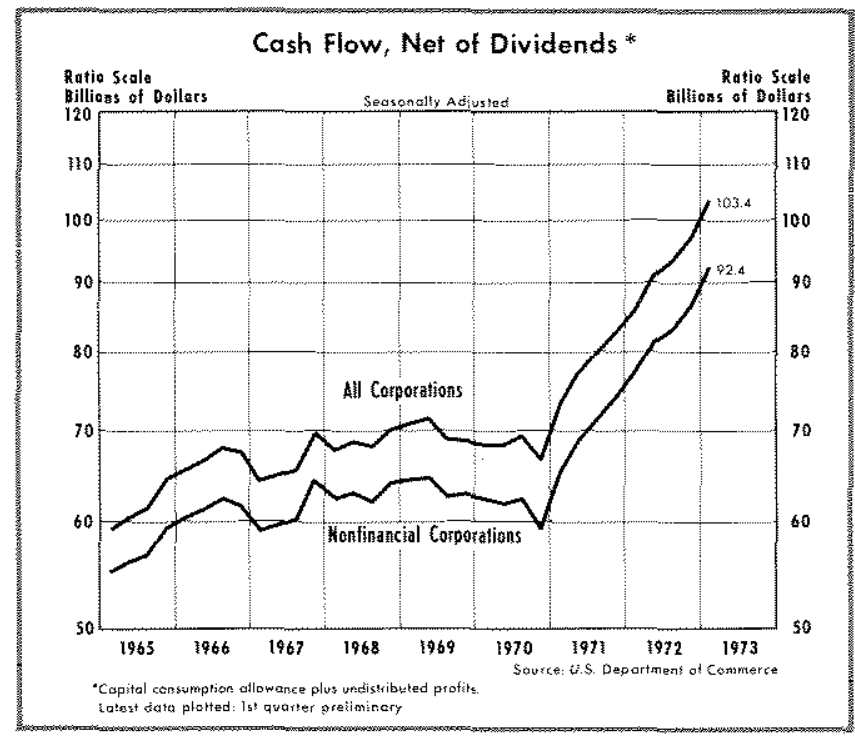

the demand for funds by savings and loan associations. Desired borrowings by the associations depends, in part, on the demand for housing - a demand which probably has begun to slow.

\section{Cotporate Sector}

As with the nonbank thrift institutions, business corporations are expected to require some increases in funds from eredit markets this year. A June 1973 Commerce Department survey reported that businessmen expected to increase plant and equipment outlays in 1973 by 13.2 percent (compared with an 8.9 percent rise in 1972 and 1.9 percent in 1971). The spring survey of the McGraw-Hill Company found a planned increase in such outlays of 19 percent in 1973.

These sizable increases in the demand for plant and equipment are anticipated because of obsolesence of many of the older facilities, the current strength of the economy, and new environmental and safety control regulations. Under some circumstances, it might be expected that the resultant demands for corporate credit would generate considerable interest rate pressures, but many business firms are currently in a position to handle much of their planned new investment with internal funds.

Corporate cash flow, which includes undistributed profits and capital consumption allowances, has increased as a result of the recent changes in depreciation rules, the re-introduction of the investment tax credit, and the 4 percent ceiling on dividend in. creases, as well as the greater corporate income that has accompanied the current economic expansion. Corporate liquidity (liquid assets relative to current liabilities) is also relatively abundant. 
Some upward pressure on short-term commercial paper interest rates may develop in 1973 if the prime bank loan rate is permitted to move to its marketdetermined level. With a substantial rise in bank interest rates, firms financing expected inventory gains would turn from bank borrowing to relatively greater issuance of commercial paper.

\section{Govermental and Forelgu Sechors}

The governmental and foreign sectors provide the exogenous or "outside" influence on U.S. credit flows. These outside factors are probably more difficult to gauge than others because they are subject to more non-economic forces.

Fiesterd Covenment - The Federal Government put considerably more pressure on the financial markets in calendar year 1966, when it had a $\$ 3.8$ billion deficit (unified budget basis), than in 1969, when it incurred a $\$ 3.2$ billion surplus. The 1966 deficit was financed largely by the sale of U.S. Government securities to the private sector.

At the time, the Federal Reserve was following restrictive policies and avoiding large Treasury security purchases. The apparent result of the Treasury and Federal Reserve actions was a "crowding out" of some private borrowers from the financial markets. In 1969 Federal Government pressures on financial markets were much less intense, despite restrictive actions by the Federal Reserve.

Earlier this year a number of analysts were projecting substantial pressures in the Treasury security market because of the large deficits anticipated in 1973. The issuance of a large volume of Treasury securities was expected if only to facilitate refunds of last year's tax overwithholding. It appears, however, that many individuals have yet to re-adjust their tax exemption schedules, resulting in a repetition of overwithholding in the current year. In addition, the growth of the economy has been more robust to date than many analysts projected. Large increases in personal and corporate incomes have resulted in greaterthan-anticipated tax receipts. ${ }^{8}$ Deficit estimates were recently revised downward from $\$ 24.8$ billion in fiscal 1973 and $\$ 12.7$ billion in fiscal 1974 to $\$ 17.8$ billion and $\$ 2.7$ billion, respectively. ${ }^{9}$

${ }^{8}$ Sales of special securities to foreign governments aromd the time of the currency crisis in early 1973 also contributed to the Government's favorable cash position.

Initial data are from the 1973 Report of the Council of Economic Advisers, and the revised estimates were taken from the "Mid-Session Review of the 1974 Budget," Office of Management and Budget, June 1, 1973 .
Sinte and Local Coverments - There is considerable evidence that the ability of state and local governments to attract funds in 1966 and 1969 was adversely affected by the prevailing financial pressures. ${ }^{10}$ Bond issuance was postponed in a number of cases until interest rates returned to more normal levels. To the extent that these governments did not "drop out of the market," however, they themselves tended to aggravate interest rate pressures.

Since mid-1969, state and local governments in the aggregate have been incurring budget surpluses. The recent implementation of Federal revenue sharing and the strength of economic activity are currently bolstering these governments' financial positions. It is probable that some state and local governments have been using portions of their heavy inflow of funds to purchase Treasury bills, thereby keeping yields on Treasury securities below what they otherwise would be.

Foreign Secior - Under certain conditions in the past, such as an expanded balance-of-payments surplus which resulted in a rise in U.S. gold receipts and an associated increase in the monetary base (not otherwise offset), foreign sector developments unambiguously influenced the volume of U.S. credit flows. In many other cases the foreign influence is not so clear.

At present, for example, foreigners hold slightly less than 19 percent of U.S. Government securities outstanding (net of debt held by U.S. Government agencies and trust funds), much of which was accumulated by foreign central banks during the international monetary turmoil of the past two years. To the extent that foreign central banks sell a portion of their approximately $\$ 63$ billion of U.S. Treasury securities in the near future, the effect would add to upward pressure on interest yields of these securities. ${ }^{11}$

A sale of this scope would not likely occur unless: 1) the interest rate on competing U.S. assets, such as certificates of deposit issued by commercial banks, rose well above the Treasury security rate; or 2) U.S. or foreign investors exchanged foreign currencies for

\footnotetext{
toSee John E. Petersen and Paul F. MoGouldrick, "Monetary" Restraint, Borrowing and Capital Spending by Small Local Governments and State Colleges in 1966," Federal Reserve Bulletin (Decernber 1968), pp. 953-982, and John E. Petersen, "Response of State and Local Governments to Varying Credit Conditions:" Federal Reserve Bulletin (March 1971), pp. $209-232$.

"See Anatol Balbach, "Will Capital Reflows Induce Domestic Interest Rate Changes?", this Review (July 1972) pp. 2-5, and Jerry L. Jordan, "Interest Rates and Monetary Growth," this Review (January 1973), pp. 2-11.
} 
dollars at the foreign central banks in order to invest in dollar denominated assets such as U.S. private bonds and equities. In either case, upward pressures on Treasury security interest rates would be accompanied by an increased demand for other types of U.S. assets.

\section{SUMNANY}

Although some similarities with earlier credit crunch periods have been noted, the economic situation in the first five months of 1973 was far removed from the type of intense financial pressures of 1966 and 1969. Distortions in credit flows, the chief characteristic of the earlier crunch periods, have occurred. These distortions, however, have not been as marked as in 1966 and 1969. Modifications of interest ceilings have permitted financial intermediaries, such as banks and nonbank thrift institutions, to compete more effectively for funds than in other periods of high and rising interest rates.

The rise in interest rates last year and so far this year appears to have resulted largely from a growing demand for credit. The current strength of the econ- omy and advancing price pressures underlie the expansion of credit demand. Some sectors, such as the variots agencies supporting the thrift institutions and the montgage market, may step up their credit demands in the ensuing months. Stronger agency sup port and the relaxation of some interest rate restrictions should make the housing industry less vulnerable to financial stress than in the past. The corporate and governmental sectors are not expected to foster significant financial pressures in the near future because of their reasonably favorable credit positions.

Key monetary aggregates, such as the monetary base, Federal Reserve credit, and commercial bank credit have increased rapidly in recent months, unlike the slowdowns observed in 1966 and 1969. A slowing in the money stock occurred for a few months in early 1973, but the slowing was not nearly as marked nor as enduring as that which occurred during the severe monetary restraint of 1966 and 1969. Consequently, despite strong credit demands and rising market interest rates, the considerable distortions in credit flows which marked the 1966 and 1969 periods were not observed in the early months of 1973 .

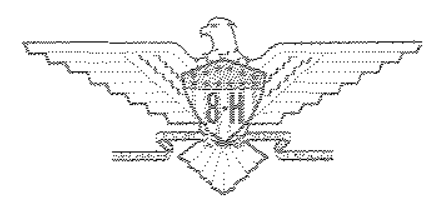

